\begin{tabular}{|c|c|c|c|c|c|}
\hline $\begin{array}{l}\text { Ref. } \\
\text { miRNA }\end{array}$ & $\begin{array}{l}\text { Cluster } \\
\text { members }\end{array}$ & Chr & $\mathrm{N}$ & Positions & Expression pattern of mature miRNA \\
\hline $124 a-3$ & & 20 & 8 & $\begin{array}{l}701087688904 \\
897790489095 \\
92939498\end{array}$ & $\begin{array}{l}\text { Brain specific miRNA; Highly } \\
\text { expressed during brain development }{ }^{1,2}\end{array}$ \\
\hline 425 & 191 & 3 & 7 & $\begin{array}{l}75478281078607 \\
863289369194\end{array}$ & Neurons $^{3}$ \\
\hline $124 a-1$ & & 8 & 6 & $\begin{array}{l}625466016624 \\
691171429426\end{array}$ & $\begin{array}{l}\text { Brain specific miRNA; Highly } \\
\text { expressed during brain development }{ }^{2}\end{array}$ \\
\hline 607 & & 10 & 6 & $\begin{array}{l}585158826150 \\
617162086659\end{array}$ & Colorectal cancer cells $(\mathrm{CC})^{4}$ \\
\hline $550-1$ & & 7 & 6 & $\begin{array}{l}479749765014 \\
554056135852\end{array}$ & $\mathrm{CC}^{4}$ \\
\hline 132 & 212 & 17 & 6 & $\begin{array}{l}320238834127 \\
881699229999\end{array}$ & Highly expressed in brain ${ }^{5}$ \\
\hline 96 & $\begin{array}{l}182 \\
183\end{array}$ & 7 & 6 & $\begin{array}{l}158028334611 \\
476549396201\end{array}$ & $\begin{array}{l}\text { Significantly expressed in dorsal root } \\
\text { ganglia }^{6} \text { (neuronal cells) and } \\
\text { embryonic stem cells (ES) }\end{array}$ \\
\hline $9-2$ & & 5 & 6 & $\begin{array}{l}115215602303 \\
251127882794\end{array}$ & $\begin{array}{l}\text { Highly expressed during brain } \\
\text { development }\end{array}$ \\
\hline 559 & & 2 & 6 & $\begin{array}{l}144316351825 \\
207524172752\end{array}$ & $\mathrm{CC}^{4}$ \\
\hline $20 a$ & $\begin{array}{l}19 \mathrm{~b}-1,92- \\
1, \\
17,19 a, 18 a\end{array}$ & 13 & 5 & $\begin{array}{l}631263287279 \\
74747942\end{array}$ & $\begin{array}{l}\mathrm{ES}^{9} \text {, Highly expressed during } \\
\text { development of skin epidermis }{ }^{10} \text {. }\end{array}$ \\
\hline 210 & & 11 & 5 & $\begin{array}{l}146023369447 \\
96189858\end{array}$ & $\begin{array}{l}\text { Predominantly expressed in Thymus } \\
\text { Abundant in pancreatic-islets }(\mathrm{PI})^{11}\end{array}$ \\
\hline 483 & & 11 & 5 & $\begin{array}{l}25731083718 \\
41884764\end{array}$ & $\mathrm{CC}^{4}$ \\
\hline 486 & & 8 & 5 & $\begin{array}{l}574580586614 \\
620\end{array}$ & Fetal development of liver ${ }^{12}$ \\
\hline 363 & $\begin{array}{l}18 b, 106 a \\
20 b, 19 b-2 \\
92-2\end{array}$ & $x$ & 4 & $\begin{array}{l}657272887445 \\
7754\end{array}$ & Prenatal embryonic development ${ }^{8}$ \\
\hline 345 & & 14 & 4 & $\begin{array}{l}846586278789 \\
8858\end{array}$ & Fetal development of liver ${ }^{12}$ \\
\hline 378 & & 5 & 4 & $\begin{array}{l}734983859218 \\
9267\end{array}$ & $\mathrm{PI}^{13}$ \\
\hline $129-2$ & & 11 & 4 & $\begin{array}{l}406484908496 \\
9884\end{array}$ & Expressed in cerebellum ${ }^{1}$ \\
\hline 181d & $181 \mathrm{c}$ & 19 & 4 & 1809029541060 & Down-regulated in glioblastoma ${ }^{14}$ \\
\hline 589 & & 7 & 4 & $\begin{array}{l}427549444955 \\
4989\end{array}$ & $\mathrm{CC}^{4}$ \\
\hline $101-1$ & & 1 & 4 & 60095210011834 & Predominantly expressed in brain ${ }^{1}$ \\
\hline $135 b$ & & 1 & 4 & $\begin{array}{l}133415981666 \\
2304\end{array}$ & Expressed in cortical neurons ${ }^{3}$ \\
\hline 375 & & 2 & 3 & 839586138904 & PI specific miRNA ${ }^{11}$ \\
\hline $9-1$ & & 1 & 3 & 884589429646 & $\begin{array}{l}\text { Highly expressed during brain } \\
\text { development }{ }^{3,8}\end{array}$ \\
\hline $92 b$ & & 1 & 3 & 952895359812 & Abundant in brain ${ }^{4}$ \\
\hline 25 & 106b,93 & 7 & 3 & 228027752917 & Widely expressed in $\mathrm{ES}^{9}$ \\
\hline
\end{tabular}


Table S2: miRNA genes that contain atleast 3 occurrences of the motif, CGCGCG within a contiguous stretch of $2 \mathrm{~kb}$ in their upstream regions $(<10 \mathrm{~kb})$. The locations of the motif (Positions) are with respect to the start of the first $10 \mathrm{~kb}$ upstream region of the reference miRNA (Ref. miRNA). The miRNAs for which the upstream regions (Cluster members) overlap with that of the reference miRNA and satisfy the criteria for the occurrences of motifs are noted for clarity. The number of occurrences $(\mathrm{N})$ of the motif upstream of the reference miRNA is also indicated.

\section{Reference List}

1. Lagos-Quintana, M., Rauhut, R., Yalcin, A., Meyer, J., Lendeckel, W. \& Tuschl, T. Identification of tissue-specific microRNAs from mouse. Curr. Biol. 12, 735-739 (2002).

2. Krichevsky, A. M., King, K. S., Donahue, C. P., Khrapko, K. \& Kosik, K. S. A microRNA array reveals extensive regulation of microRNAs during brain development. RNA. 9, 1274-1281 (2003).

3. Kim, J., Krichevsky, A., Grad, Y., Hayes, G. D., Kosik, K. S., Church, G. M. \& Ruvkun, G. Identification of many microRNAs that copurify with polyribosomes in mammalian neurons. Proc. Natl. Acad. Sci. U. S. A 101, 360-365 (2004).

4. Cummins, J. M., He, Y., Leary, R. J., Pagliarini, R., Diaz, L. A., Jr., Sjoblom, T., Barad, O., Bentwich, Z., Szafranska, A. E., Labourier, E., Raymond, C. K., Roberts, B. S., Juhl, H., Kinzler, K. W., Vogelstein, B. \& Velculescu, V. E. The colorectal microRNAome. Proc. Natl. Acad. Sci. U. S. A (2006).

5. Sempere, L. F., Freemantle, S., Pitha-Rowe, I., Moss, E., Dmitrovsky, E. \& Ambros, V. Expression profiling of mammalian microRNAs uncovers a subset of brain-expressed microRNAs with possible roles in murine and human neuronal differentiation. Genome Biol. 5, R13 (2004).

6. Kloosterman, W. P., Wienholds, E., de, B. E., Kauppinen, S. \& Plasterk, R. H. In situ detection of miRNAs in animal embryos using LNA-modified oligonucleotide probes. Nat. Methods 3, 27-29 (2006).

7. Houbaviy, H. B., Murray, M. F. \& Sharp, P. A. Embryonic stem cell-specific MicroRNAs. Dev. Cell 5, 351-358 (2003).

8. Mineno, J., Okamoto, S., Ando, T., Sato, M., Chono, H., Izu, H., Takayama, M., Asada, K., Mirochnitchenko, O., Inouye, M. \& Kato, I. The expression profile of microRNAs in mouse embryos. Nucleic Acids Res. 34, 1765-1771 (2006).

9. Thomson, J. M., Parker, J., Perou, C. M. \& Hammond, S. M. A custom microarray platform for analysis of microRNA gene expression. Nat. Methods 1, 47-53 (2004).

10. Yi, R., O'carroll, D., Pasolli, H. A., Zhang, Z., Dietrich, F. S., Tarakhovsky, A. \& Fuchs, E. Morphogenesis in skin is governed by discrete sets of differentially expressed microRNAs. Nat. Genet. (2006).

11. Poy, M. N., Eliasson, L., Krutzfeldt, J., Kuwajima, S., Ma, X., Macdonald, P. E., Pfeffer, S., Tuschl, T., Rajewsky, N., Rorsman, P. \& Stoffel, M. A pancreatic islet-specific microRNA regulates insulin secretion. Nature 432, 226-230 (2004).

12. Fu, H., Tie, Y., Xu, C., Zhang, Z., Zhu, J., Shi, Y., Jiang, H., Sun, Z. \& Zheng, X. Identification of human fetal liver miRNAs by a novel method. FEBS Lett. 579, 3849-3854 (2005). 
13. Fernandez-Zapico, M. E., Bramati, P. S., Zakaria, S., Kaczynski, J. A. \& Urrutia, R. Fundamentals of transcription factors and their impact on pancreatic development and cancer. Pancreatology. 3, 276-283 (2003).

14. Ciafre, S. A., Galardi, S., Mangiola, A., Ferracin, M., Liu, C. G., Sabatino, G., Negrini, M., Maira, G., Croce, C. M. \& Farace, M. G. Extensive modulation of a set of microRNAs in primary glioblastoma. Biochem. Biophys. Res. Commun. 334, 1351-1358 (2005). 